\title{
CHORDAE TENDINEAE ARCHITECTURE IN THE PAPILLARY MUSCLE INSERTION
}

\author{
ARQUiTECTURA DE LAS CUERDAS TENDINOSAS EN LA UNIÓN CON EL MÚSCULO PAPILAR
}

\author{
Luciana Wang Gusukuma; José Carlos Prates \& Ricardo Luiz Smith
}

GUSUKUMA, W. L.; PRATES, J. C. \& SMITH R. L. Chordae tendineae architecture in the papillary muscle insertion. Int. J. Morphol., 22(4):267-272, 2004.

SUMMARY: Chordae tendineae architecture and their junction with papillary muscle were studied with scanning electron microscopy, comparing human and swine hearts. Papillary muscles with the corresponding chordae tendineae were obtained from human and pig (Sus scrofa) hearts after exposition of the left ventricle cavity, fixed with $4 \%$ formaldehyde. The specimens were sectioned in small samples and divided in four groups, a control one and the others submitted to digestion in a solution of $2.5 \%$ sodium hypochlorite in saline solution during 5, 10 and 15 minutes respectively. The specimens were washed and fixed in 1\% osmium tetroxide in cacodylate buffer, kept in $1 \%$ tannic acid for 30 minutes, dehydrated and critical point dried, mounted and sputtered with gold. The specimens were examined and documented in a JEOL 5200 scanning electron microscope. The human and swine chordae tendineae have similar architecture: both are covered by the endothelium which was in continuity with the papillary muscles, the inner layers are composed by longitudinal and oblique collagen bundles intermingled with elastic fibers. Differences between swine and human hearts were found in the chordae tendineae papillary muscle junction. In the human heart the collagen bundles showed a more organized arrangement, forming a meshwork with the fibers disposed in approximately orthogonal angles, whereas in the swine heart the fibers were randomly disposed.

KEY WORDS: 1. Chordae tendineae; 2. Architecture; 3. Human; 4. Pigs; 5. Scanning electron microscopy.

\section{INTRODUCTION}

As a requirement for the pumping function, the heart must have a determined arrangement of the ventricular muscle fibers (Ingels, 1997). The papillary muscle and the trabeculae carneae are formed by the ventricular fibers originated from the cardiac muscle layers which project into the ventricular left cavity. Those structures are in direct contact with blood flow and actuate determining the adequate blood course, participating directly in the myocardium contractile function.

The structure of left atrioventricular valve apparatus is composed by the mitral annulus, mitral valve leaflets, chordae tendineae and papillary muscles and has been studied elsewhere (Silverman \& Hurst, 1968; Lam et al., 1970; Lim \& Boughner, 1976; Millington-Sanders et al., 1998) concerning the diseases that attempt its integrity and function, including its morphogenesis (Morse et al., 1984; Oosthoek et al., 1998).

Several pathologies can result in anatomical and functional abnormalities of the papillary muscle as ischemia, fibrosis and rupture (Roberts \& Cohen, 1972) and also of the chordae tendineae that are abnormally long, abnormally short, ectopically inserted or ruptured (Caulfield et al., 1971; Perloff \& Roberts; Scott-Jupp et al., 1981). These structures damage impair the mitral apparatus function resulting in mitral regurgitation.

Mechanical properties of mitral valve apparatus depend to large extend on the link between papillary muscle and valve that transmit contractions of the muscle to the valve leaflets. This link is represented by the tendinous chordae composed by a network of collagen and elastic fibers (Millington-Sanders et al., 1998). Mechanical behavior of mitral valve chordae tendineae is intimately related to the microstructural arrangement of the fibrous components (Lim \& Boughener, 1976; Liao \& Vesely, 2003).

The chordae tendineae study is relevant because the possibility of surgical repair or replacement by different materials (Revuelta et al., 1989). Considering that experimental models are necessary to develop new approaches, we studied swine and human chordae tendineae. 
The objective of this investigation is the study of chordae tendineae architecture and their junction with papillary muscle by scanning electron microscopy, comparing human and swine hearts.

\section{MATERIAL AND METHOD}

Hearts from humans and pigs (Sus scrofa) were fixed in $4 \%$ buffered formaldehyde and dissected to expose the left ventricle cavity. It was excised 24 papillary muscles with the corresponding chordae tendineae which were processed for scanning electron microscopy. The specimens were sectioned in small samples and divided in four groups, a control one and the others submitted to digestion in a solution of 2.5\% sodium hypochlorite in saline solution during 5, 10 and 15 minutes respectively. The sequence of the protocol was: washing in $0.1 \mathrm{M}$ sodium cacodilate buffer, fixation in $1 \%$ osmium tetroxide in the same buffer, washing and $1 \%$ tannic acid for 30 minutes, dehydration in a graded ethanol series, critical point drying with $\mathrm{CO}_{2}$ (Balzers CPD 030), mounting in stubs and gold sputtering was performed (Balzers SCD 050). The specimens were examined and documented in a JEOL 5200 scanning electron microscope with voltage acceleration of $25 \mathrm{KV}$.

\section{RESULTS}

The control samples showed the junction between the chordae tendineae and the papillary muscles covered by the endocardium endothelium which was in continuity in the two anatomic structures (Figs. 1 and 2).

A single papillary muscle may originate multiple chordae tendineae which can divide into branches, aspect noticed in swine and human hearts (Fig. 3).

The sodium hypochlorite digestion during different periods exposed the fiber arrangement of the chordae tendineae and of the region where it inserts in the papillary muscle (Figs. 4 and 5). At five minutes of digestion, the endothelium was detached showing the subjacent fibers layer (Fig. 4).

The fibers that constitute the chordae tendineae form bundles arranged in layers with a predominantly longitudinal disposition (Figs. 6 and 7). The prolonged digestion demonstrated the successive layer disposition sometimes with different orientation arrangements between each other (Fig. 8). Fibers of higher diameter were recognized (collagen) closely to thin fibers which form a network around the former (Figs. 9 and 10).

In the chordae-papillary muscle junction region, the fibers compose a dense interwoven (Figs. 11 and 12). Some differences between swine and human hearts were found in the junction region. In the human heart the collagen bundles showed a more organized arrangement, forming a meshwork with the fibers disposed in approximately orthogonal angles (Fig. 11), whereas in the swine heart the fibers were randomly disposed (Fig. 12).

\section{DISCUSSION}

The left ventricle papillary muscles originate as a component of the interlacing traeculae carneae (Silverman \& Hurst), present its fibers arising from the circular myocardium layer in the core portion and from the inner longitudinal myocardium layer recovering the former, composing the outer portion. These muscle fibers originate the chordae tendineae that inserts in the atrioventricular valve margin. A single papillary muscle in swine and human hearts may originate several chordae tendineae which after that may divide in several branches as described previously (Lam et al.; Roberts \& Cohen). As observed with the scanning electron microscope, the endocardium endothelia that recover the papillary muscle are in continuity with the chordae tendineae lining. The junction between papillary muscle and chordae tendineae examined under scanning electron microscopy after sodium hypochlorite digestion is composed by collagen fibers organized in different way comparing human and swine hearts. Dense fibers interwoven organized as a crossed network was demonstrated in the human heart. This aspect has already been showed in human chordae histological tangential sections (Millington-Sanders et al.). In the swine, the fibers were disposed at random. Our results suggest that the human and swine chordae junction have different mechanical properties. By other hand, the architectural disposition of the chordae fiber components out of the junction is similar in both specimens.

Hypochlorite digested chordae showed a lamellar disposition formed by collagen bundle sheaths with longitudinal orientation. Fine elastic fibers intermingled with collagen bundles, are randomly and occasionally perpendicular oriented in relation to collagen fascicules. Such organization and the fibers physical properties are intimately linked with chordae mechanical behavior in tension. Strain resistance and elasticity are provided by the fibers characteristics. The organization of the two main chordae constituents was described by Morse et al. and Millington- 

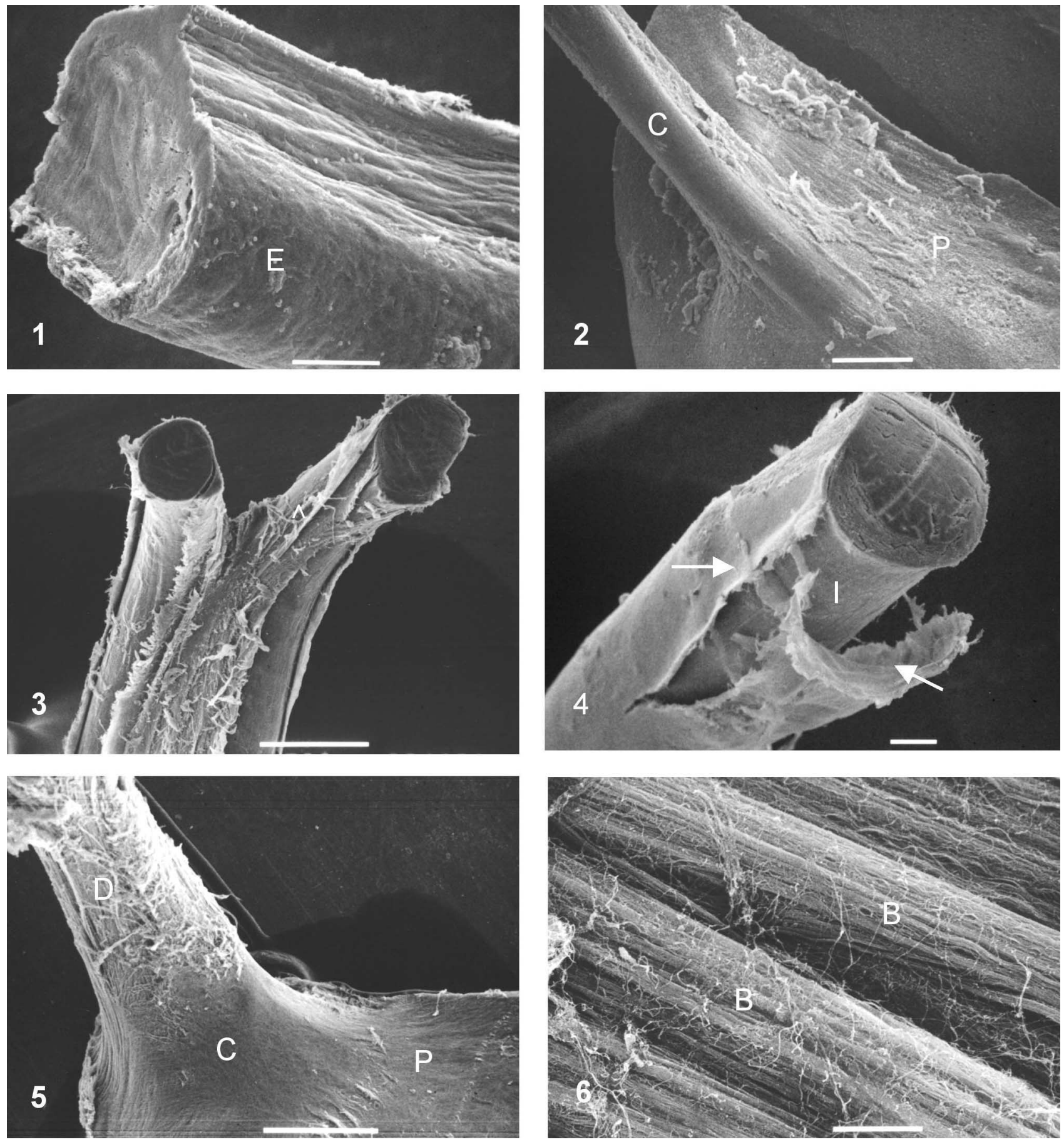

Figs. 1-6. Chordae tendineae scanning electron micrographs.

Fig. 1. Human heart (control group) - E: endotelium (bar $=100 \mu \mathrm{m})$.

Fig. 2. Swine heart (control group) - C: chordae tendineae; P: papillar muscle (bar $=500 \mu \mathrm{m})$.

Fig. 3. Human heart (hypochlorite 15') - *: digested sheaths (bar $=500 \mu \mathrm{m})$.

Fig. 4. Human heart (hypochlorite 5') - I: inner fibers; arrows: disengaged outer layer $(\mathrm{bar}=100 \mu \mathrm{m})$.

Fig. 5. Swine heart (hypochlorite 5') - C: chordae tendineae; P: papillar muscle; D: chordae digested area $(\mathrm{bar}=500 \mu \mathrm{m})$.

Fig. 6. Swine heart (hypochlorite 15') - B: collagen fibers bundles $(\mathrm{bar}=10 \mu \mathrm{m})$. 

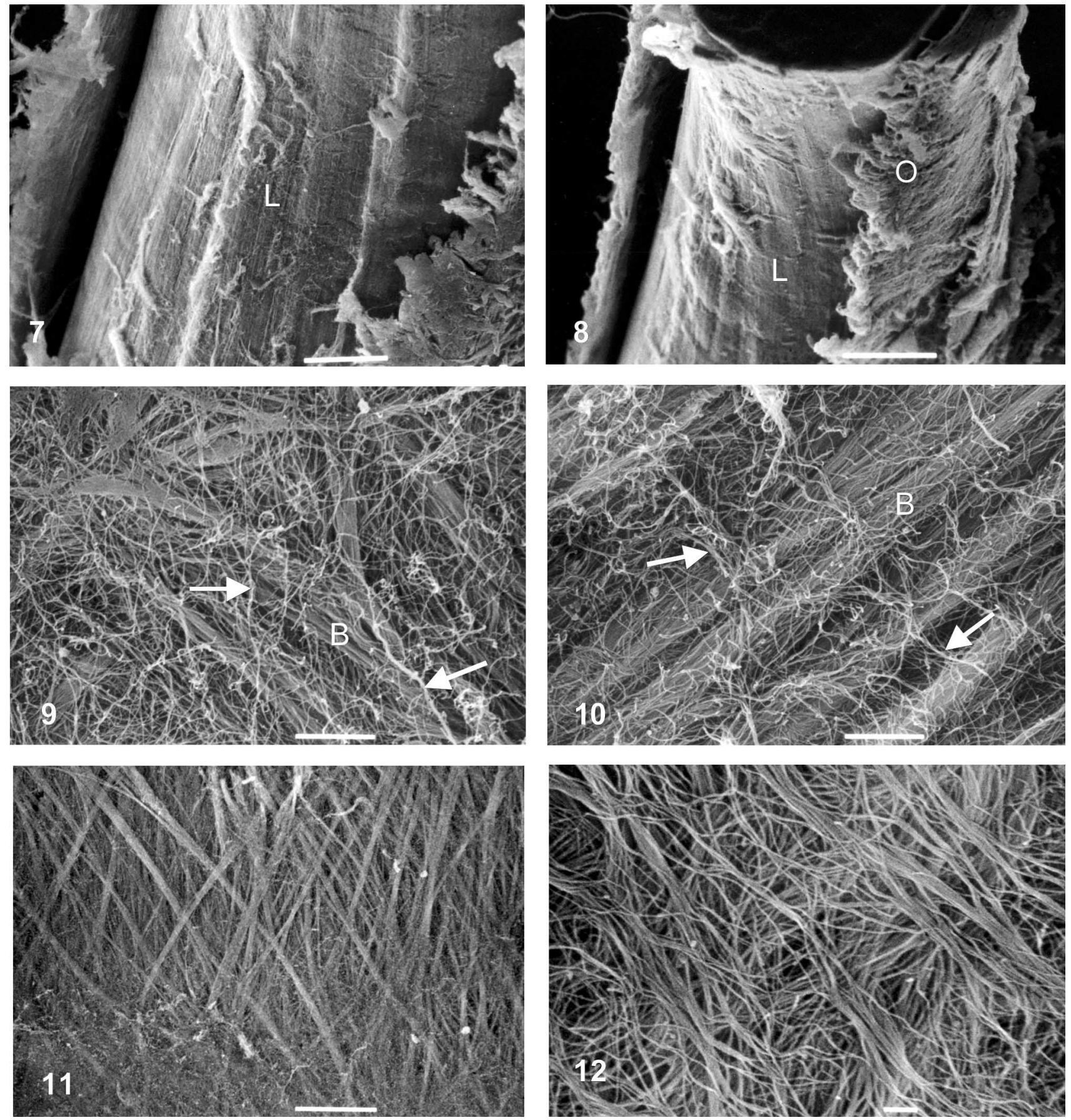

Figs. 7-10. Chordae tendineae scanning electron micrographs.

Fig. 7. Human heart (hypochlorite 15') - L: longitudinal collagen fibers $(\mathrm{bar}=50 \mu \mathrm{m})$.

Fig 8. Human heart (hypochlorite 15') - L: deep longitudinal collagen fibers; O: superficial oblique collagen fibers $($ bar $=100 \mu \mathrm{m})$.

Fig. 9. Swine heart (hypochlorite 15') - B: collagen fibers bundles; arrows: elastic fibers (bar $=5 \mu \mathrm{m}$ ).

Fig 10. Human heart (hypochlorite 15') - B: collagen fibers bundles; arrows: elastic fibers (bar $=5 \mu \mathrm{m})$.

Figs. 11 and 12. Papillary muscle and chordae junction scanning electron micrographs.

Fig. 11. Human heart (hypochlorite 10') - organized orthogonal arrangement of collagen fibers ( $\mathrm{bar}=50 \mu \mathrm{m})$.

Fig. 12. Swine heart (hypochlorite 15') - randomly arranged collagen fibers (bar $=1 \mu \mathrm{m}$ ). 
Sanders et al. According the authors, chordae tendineae essential framework are constituted by a collagen fibers central core recovered by elastic fibers and both enveloped by endothelium. The connective tissue components of normal chordae tendineae were identified as collagen type I and III, elastin, fibronectin and vitronectin using immunolocalization (Akhtar et al., 1999).

The chordae has nonlinear viscoelastic properties in that extensibility decrease with increasing strain rates, typical of collagen fibers. Enzymatic digestion of chordae elastin did not significantly affect the elastic response under strain
(Lim \& Boughner, 1975; 1976). Thus, the probable role of elastic fibers is to keep collagen fibers together during chordae stress and relaxation.

Abnormalities of those left atrioventricular valve components could lead to pathologies that affect its function, by instance mitral insufficiency or mitral prolapse (Perloff \& Roberts; Oosthoek et al.).

Acknowledgement: To the Electron Microscopy Unity (CEME-UNIFESP) for the facilities and CNPq (PIBIC) financial support.

GUSUKUMA, W. L.; PRATES, J. C. \& SMITH R. L. Arquitectura de las cuerdas tendinosas en la unión con el músculo papilar. Int. J. Morphol., 22(4):267-272, 2004.

RESUMEN: La arquitectura de las cuerdas tendinosas y su unión con el músculo papilar fueron estudiados a través de microscopía electrónica de barrido, comparando corazones humanos y de cerdos. Músculos papilares con sus correspondientes cuerdas tendinosas fueron obtenidos de corazones humanos y de cerdos (Sus scrofa), después de la exposición de la cavidad ventricular izquierda, y fijados con formaldehido al 4\%. Los especímenes fueron seccionados en pequeñas muestras y divididas en cuatro grupos, una control y las otras sometidas a la hidrólisis en una solución de hipoclorito de sodio al 2.5\% en solución salina durante 5, 10 y 15 minutos, respectivamente. Los especímenes fueron lavados y fijados en tetróxido de osmio al $1 \%$ en buffer cacodylate, mantenidos al 1\% en ácido tánico por 30 minutos, deshidratados y secadas en punto crítico, montados y impregnadas con oro. Los especímenes fueron examinados y documentados en un microscopio electrónico de barrido JEOL 5200. Las cuerdas tendinosas humanas y de cerdos tienen una arquitectura similar: ambas están cubiertas por un endotelio, el cual está en continuidad con los músculos papilares, las capas interiores están compuestas por haces de fibras colágenas longitudinales y oblicuas entremezcladas con fibras elásticas. Diferencias entre corazones humanos y de cerdos fueron encontradas en la unión de las cuerdas tendinosas y el músculo papilar. En el corazón humano los haces de colágenos se mostraron más organizados, formando una malla con las fibras dispuestas en ángulos aproximadamente octogonales, en cambio, en el corazón de cerdo estaban dispuestas al azar.

PALABRAS CLAVE: 1. Cuerdas tendinosas; 2. Arquitectura; 3. Humano; 4. Cerdo; 5. Microscopía electrónica de barrido.

\section{REFERENCES}

Akhtar, S.; Meek, K.M. \& James, V. Immunolocalization of elastin, collagen type I and type III, fibronectin, and vitronectin in extracellular matrix components of normal and myxomatous mitral heart valve chordae tendineae. Cardiovasc. Pathol., 8(4):203-11, 1999.

Caulfield, J. B.; Page, D. L.; Kastor, J. A. \& Sanders, C. A. Connective tissue abnormalities in spontaneous rupture of chordae tendineae. Arch. Pathol., 91:537$41,1971$.

Ingels, N. B. Jr. Myocardial fiber achitecture and left ventricular function. Technol. Health Care, 5(1-2):45$52,1997$.

Lam, J.H.; Ranganathan, N.; Wigle, E.D. \& Silver, M.D. Morphology of the human mitral valve. I. Chordae tendineae: a new classification. Circulation, 41:449-58, 1970 .
Liao, J. \& Vesely, I. Structural basis for the size-related mechanical properties of mitral valve chordae tendineae. J. Biomech., 36:1125-33, 2003.

Lim, K.O. \& Boughner, D.R. Mechanical properties of human mitral valve chordae tendineae: variation with size and strain rate. Can. J. Physiol. Pharmacol., 53(3):330-9, 1975.

Lim, K. O. \& Boughner, D. R. Morphology and relationship to extensibility curves of human mitral valve chordae tendineae. Circ. Res., 39(4):580-5, 1976.

Millington-Sanders, C.; Meir, A.; Lawrence, L. \& Stolinski, C. Structure of chordae tendineae in the left ventricle of the human heart. J. Anat., 192(Pt 4):573-81, 1998.

Morse, E. D.; Hamlett, W.C. \& Noble, C. W. Morphogenesis of chordae tendineae. I: Scanning electron microscopy. Anat. Rec., 210:629-38, 1984. 
Oosthoek, P. W.; Wenink, A. C.; Wisse, L. J. \& Gittenbergerde Groot, A.C. Development of the papillary muscles of the mitral valve: morphogenetic background of parachute-like asymmetric mitral valves and other mitral valve anomalies. J. Thorac. Cardiovasc. Surg., 116(1):36-46, 1998.

Perloff, J. K. \& Roberts, W. C. The mitral apparatus: Functional anatomy of mitral regurgitation. Circulation, 46:227-38, 1972.

Revuelta, J. M.; Garcia-Rinaldi, R.; Gaite, L.; Val, F. \& Garijo, F. Generation of chordae tendineae with polytetrafluoroethylene stents. Results of mitral valve chordal replacement in sheep. J. Thorac. Cardiovasc. Surg., 97(1):98-103, 1989.

Roberts, W.C. \& Cohen, L.S. Left ventricular papillary muscles. Circulation, 46:138-53,1972.

Scott-Jupp, W.; Barnett, N. L.; Gallagher, P. J.; Monro, J. L. \& Ross, J. K. Ultrastructural changes in spontaneous rupture of mitral chordae tendineae. J. Pathol., 133:185201, 1981.

Silverman, M. E. \& Hurst, J.W. The mitral complex. Am. Heart J.,76(3):399-418, 1968.
Corresponce to:

Prof. Dr. Ricardo Luiz Smith PhD., M.D.

Departamento de Morfologia, ULNIFESP

Rua Botucatu 740

CEP 04023-900

São Paulo, SP

BRASIL

Phone: 55-11-55796700

Fax: 55-11-55717597

Email: rlsmith.morf@epm.6r

Received : 18-08-2004

Accepted: 12-10-2004 